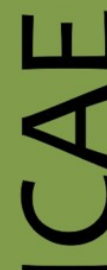

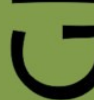

ex Instituto Archaeologico Universitatis de Rolando Eötvös nominatae

O

$\overrightarrow{0}$

山

$\leftarrow$

I

$\cup$

ه

$\leftarrow$

u

Ш

Z

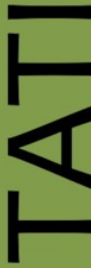

œ

ш

n

n

$\varnothing$
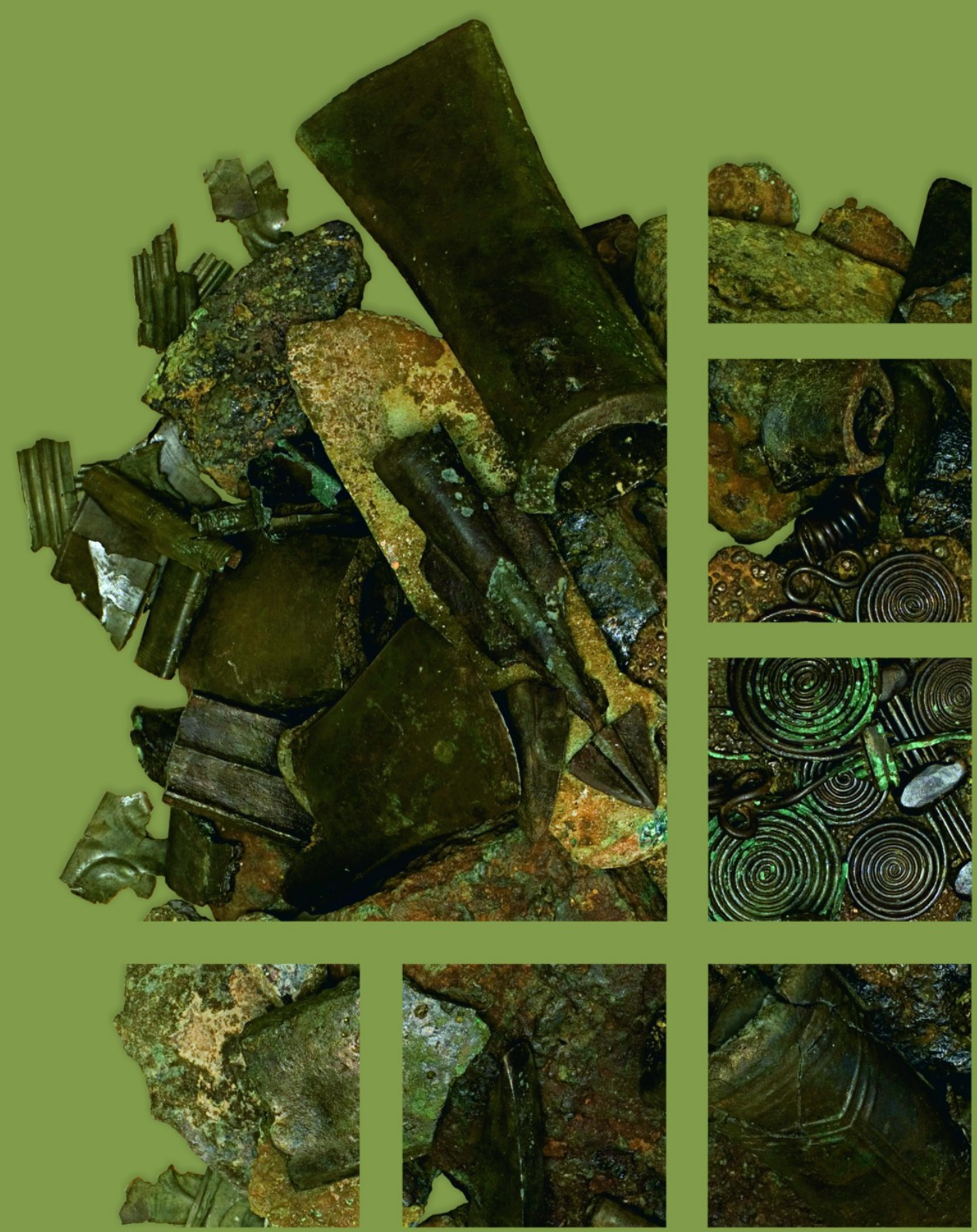


\section{Dissertationes Archaeologicae ex Instituto Archaeologico}

Universitatis de Rolando Eötvös nominatae Ser. 3. No. 2.

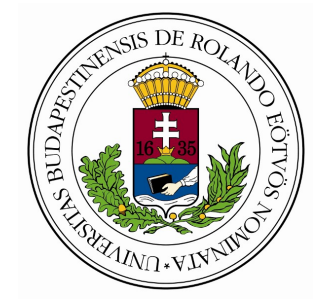

Budapest 2014 
Dissertationes Archaeologicae ex Instituto Archaeologico Universitatis de Rolando Eötvös nominatae

Ser. 3. No. 2.

Editor-in-chief:

DÁvid BARTus

Editorial board:

LÁsZló BARTOSIEWICZ

LÁSZLÓ BORHY

IsTVÁN FELD

GÁBOR KALLA

PÁL RACZKY

MiKLÓs SzABÓ

TIVADAR VIDA

Technical editors:

DÁvid BARTus

GÁBOR VÁCZI

ANDRÁs BÖDŐCS

DÁNIEL SZABÓ

Proofreading:

SZILVIA SzÖLLősI

Available online at http://dissarch.elte.hu Contact: dissarch@btk.elte.hu

$$
\begin{aligned}
& \text { PUBLIC } \\
& \text { KNOWLEDGE } \\
& \text { PROJECT }
\end{aligned}
$$

(c) Eötvös Loránd University, Institute of Archaeological Sciences

Budapest 2014 


\section{Contents}

\section{SElected PAPERS OF THE XI. Hungarian CONFERENCE on Classical Studies}

Ferenc BARNA

Venus mit Waffen. Die Darstellungen und die Rolle der Göttin in der Münzpropaganda

der Zeit der Soldatenkaiser (235-284 n. Chr.)

Dénes GABLER

A belsó vámok szerepe a rajnai és a dunai provinciák importált kerámiaspektrumában

Lajos MATHÉDESZ

Római bélyeges téglák a komáromi Duna Menti Múzeum gyújteményében

Katalin OtTOMÁNYI

Újabb római vicusok Aquincum territoriumán

Eszter SÜVEGH

Hellenistic grotesque terracotta figurines. Problems of iconographical interpretation

András SzABó

Some notes on the rings with sacred inscriptions from Pannonia

István VIDA

The coinage of Flavia Maxima Helena

\section{Articles}

Gábor TARBAY

Late Bronze Age depot from the foothills of the Pilis Mountains

Csilla SÁRó

Roman brooches from Paks-Gyapa - Rosti-puszta

András BöDőcs - Gábor KovÁcs - Krisztián ANDERKó

The impact of the roman agriculture on the territory of Savaria

Lajos JuHÁsz

Two new Roman bronzes with Suebian nodus from Brigetio

\section{FIELD REPORTS}

Zsolt MESTER - Norbert FARAGó - Attila KirÁLy

The first in situ Old Stone Age assemblage from the Rába Valley, Northwestern Hungary

Pál RACZky - Alexandra ANDERs - Norbert FARAgó - Gábor MÁRKus

Short report on the 2014 excavations at Polgár-Csőszhalom 
Preliminary Report on the first season of fieldwork in Berettyóúffalu-Szilhalom

Márton SzILÁgyi - András FüZESI - Attila VIRÁG - Mihály GASPARIK

A Palaeolithic mammoth bone deposit and a Late Copper Age Baden settlement and enclosure

Preliminary report on the rescue excavation at Szurdokpüspöki - Hosszú-dúlö II-III. (M21 site No. 6-7)

Kristóf FüLÖP - Gábor VÁcZI

Preliminary report on the excavation of a new Late Bronze Age cemetery

from fobbágyi (North Hungary)

Lőrinc TimÁr - Zoltán CzAJLik - András BöDőcs - Sándor PuszTA

Geophysical prospection on the Pâture du Couvent (Bibracte, France). The campaign of 2014

Dávid BARtus - László Borhy - Gabriella Delbó - Emese SzÁmadó

Short report on the excavations in the civil town of Brigetio (Szőny-Vásártér) in 2014

Dávid BARTus - László BorHy - Emese SzÁMADó

A new Roman bath in the canabae of Brigetio

Short report on the excavations at the site Szőny-Dunapart in 2014

Dávid BARTus - László Borhy - Zoltán CzAjlik - Balázs Holl -

Sándor PuszTA - László RuPNiK

Topographical research in the canabae of Brigetio in 2014

Zoltán CZAJLIK - Sándor BERECKI - László RUPNIK

Aerial Geoarchaeological Survey in the Valleys of the Mureș and Arieș Rivers (2009-2013)

Maxim MoRDovin

Short report on the excavations in 2014 of the Department of Hungarian Medieval

and Early Modern Archaeology (Eötvös Loránd University, Budapest)

Excavations at Castles Čabrad' and Drégely, and at the Pauline Friary at Sáska

\section{Thesis Abstracts}

Piroska Csengeri

Late groups of the Alföld Linear Pottery culture in north-eastern Hungary

New results of the research in Borsod-Abaúj-Zemplén County

Ádám Bíró

Weapons in the 10-11th century Carpathian Basin

Studies in weapon technology and methodology - rigid bow applications and southern import

swords in the archaeological material

Márta DARÓcZI-SzABó

Animal remains from the mid 12th-13th century (Árpád Period) village of Kána, Hungary

Károly BELÉNYESY

A 15th-16th century cannon foundry workshop in Buda

Craftsmen and technology of cannon moulding and the transformation of military technology

from the Renaissance to the Post Medieval Period 
István RINGER

Manorial and urban manufactories in the 17th century in Sárospatak

\section{BIBLIOGRAPHY}

László BORHY

565

Bibliography of the excavations in Brigetio (1992-2014) 


\title{
Some notes on the rings with sacred inscriptions from Pannonia
}

\author{
ANDRÁs SZABó \\ Hungarian National Museum \\ szabo.andras.022@gmail.com
}

\begin{abstract}
More than a hundred rings bearing inscriptions are known from the territory of Roman Pannonia. Among these close to 30 artefacts can be regarded as rings displaying inscriptions of religious significance. Besides the Silvanus rings, well-known to the archaeological research, some new groups of rings featuring sacred inscriptions can be distinguished according to the dedications. The aim of this paper is to analyse these objects and their religious backgrounds with the help of some archaeological, epigraphical and literary sources and to point out some of the questionable observations of the earlier research.
\end{abstract}

\section{Rings with sacred inscriptions}

From the territory of Pannonia, more than a hundred inscribed rings are known to the scholarly research. Most of these inscribed objects bear the name of their owner, sometimes in retrograde scripture, corresponding to the practical usage of finger rings, i. e. as the tools of personal identification for their respective owner. ${ }^{1}$ Some other rings contain inscriptions wishing good health and fortune, ${ }^{2}$ while others can be interpreted as so-called fidelity rings. ${ }^{3}$

A distinct group is formed by the finger rings featuring religious inscriptions. Rings depicting christogrammata ${ }^{4}$ should not be included here, since such symbols were not used exclusively for reflecting the religious preferences of the wearer, but rather as a mere decorational motif or a sign expressing loyality towards the Christian emperor. ${ }^{5}$ The magical gems ${ }^{6}$ should also be excluded from this group, as in those cases not necessarily the ring, but the gem per se was the item with the religious connotation. Rings that may be interpreted as artefacts used during magical practices must also be counted among the rings with religious inscriptions. ${ }^{7}$

There are surprisingly few written sources concerning the usage of finger rings as votive offerings ${ }^{8}$ but none of them mentions inscribed rings. Such votive rings were most probably deposited in the temples or shrines of the corresponding deities, ${ }^{9}$ and - as archaeological finds also suggest - were generally made of precious metals. ${ }^{10}$

\footnotetext{
* I would like to extend my sincere gratitude towards Ádám Szabó (Hungarian National Museum / University of Pécs) for his generous help provided during the course of my work.

1 Fourlas 1971, 76-82; Tóth 1986, 18-20; FAcsÁdy 2009, 29-30; cf. Plutarchos, Sulla, 3; Plutarchos, Pompeius, 80; Iuvenalis 13, 136-139; Plinius minor, Epistulae, 10, 84, Historia Augusta, vita Hadriani, 26.

2 e. g. Тóth 1979, 160, Nr. 5, Abb. 2, 5; FACsÁDy 2009, Kat. 54 = TitAq 1431; FÜKÖH 2011, 114.

3 Noll 1974, 241-243.

4 SPIER 2007, 184-186.

5 Tótн 1997, 365; То́тн 2008, 55; NemÉNyi 2014 - Rings displaying the name of Jesus Christ should be handled similarly to the rings displaying christogrammata.

6 For a summary, see Bonner 1950; Michel 2004; EnTwistle - AdAms 2011; NAGy 2013.

7 SzABó (manuscript).

8 Kropp 2008, 3.2/76. = AE 1983, 633 (Bath/UK); CIL II, 326 (Peñaflor/E).

9 KROPP 2008, 3.2/76. v. 1.: „Basilia donat in templum Martis anulum argenteum (...)”- cf. RIB 2422.36-40.

10 See below.
} 


\section{a.) Silvanus rings (Cat. 1-12)}

The first group of rings with sacred inscriptions are formed by the so-called Silvanus rings, ${ }^{11}$ which are exclusively known from the territory of Pannonia so far. Apart from 11 rings (Cat. 1-11), possibly another fragment from Zurndorf (A) (Cat. 12) can be defined as a Silvanus-ring. ${ }^{12}$ Silvanus was one of the most popular deities in Roman Pannonia, and his various aspects represented various indigenous gods. ${ }^{13}$ These rings can be dated to the late 3rd 4th centuries $\mathrm{AD},{ }^{14}$ and all of them are either made of gold or silver. They are usually simple, polygonal rings bearing their inscriptions (dedicated to Silvanus) on the hoop. Some of these inscriptions invoke Silvanus Viator (Cat. 1-3, 8-9, 11), a chtonic-psychopompic aspect ${ }^{15}$ of the deity, which is undoubtedly related to the fact, that the only two rings of this type with known contexts were found in graves. ${ }^{16}$ However, since not all these rings are dedicated to Silvanus Viator, and most of the rings are from unknown contexts, it is uncertain if all the rings should be interpreted as sepulchral objects. For example, the Silvanus-ring from Scarbantia (Cat. 4) bears the dedicatory formula $v$ (otum) l(ibens) m(erito) s(olvit), suggesting a votive dedication, ${ }^{17}$ rather than sepulchral usage or a dedication for the underworld. ${ }^{18}$ Based on the typological and epigraphical analogies, the extension of the letters $S$ S to the inscription as S(ilvano) s(acrum) or S(ancto) S(ilvano) seems plausible, but other possibilities could also be taken into consideration. The two Silvanus rings from known contexts (Cat. 3, 8) are from graves and they both feature the dedication to Silvanus Viator, while other Silvanus rings, containing a dedicatory formula or the term „votum” (Cat. 1, 4, 5, 7), are usually only dedicated to Silvanus without any closer denomination of the deity's aspect, ${ }^{19}$ i. e. we can only interpret the rings dedicated explicitly to Silvanus Viator as sepulchral rings or rings with dedication to the underworld, while the other Silvanus rings, with uncertain dedication (or with uncertain solution for their inscriptions) could only be regarded as votive rings, since their exact archaeological contexts are unknown.

\section{b.) Nixus rings (Cat. 13-17)}

There are a total of five rings known from Pannonia that are dedicated to the Nixus, ${ }^{20}$ out of which four (Cat. 13-16) were found in Carnuntum. Outside Pannonia, only one specimen is known from a 3rd century AD silver hoard found near Rembrechts (D) ${ }^{21}$ (Fig. 1a). Besides the finger rings, the Nixus are rarely mentioned in any kind of inscriptions: the name of the deities only occurs on an altar from Aquileia ${ }^{22}$ and on a graffito from Mauer an der Url (A). ${ }^{23}$ The graffito is inscribed on a ceramic jug, and was found in a woman's grave; ${ }^{24}$ its reading is the following: NIXIBVS SANCTIS PRO SALVTE CO(n)STVTES. The inscription of the small altar

\footnotetext{
11 For a summary with all the earlier literature see Tóтн 1978; Tóтн 1989; SzAвó 2010. 12 FbÖ 27 (1988), 302, Abb. 461 (Zurndorf/A),

13 DoRcey 1992, 14-32; Tóth 2004, 62-72.

14 HENKEL 1913, 219-221.

15 Tóth 1978, 96-97; Borhy - SzÁmadó 2003, 53; Szabó 2010, 223-228.

16 Kraskovská 1974, 28, Obr. 20 (Gerulata, Grave 25); Burger 1962, 118, 13. kép (Bogád, Grave 12).

17 WisSOWA 1912, 381-382.

18 cf. SzABó 2008, 165-166.

19 In one instance, the ring is dedicated to Silvanus Silvester (Cat. 10).

20 The noun nixus, nixus, masc. (meaning childbirth and labour) is a derivative of the the deponent verb nitor, niti, nixus sum (meaning: leaning onto something, to strain oneself, to be in labour, to give birth).

21 Noll 1985, 159, Abb. 1.

22 AE 1934, 238.

23 AE 1975, 671.

24 SAŠEL Kos 1999, 188.
} 
from Aquileia can be read as NIXIBVS / LVCINIS / [---]PARIA / [---]S, while G. Brusin proposed the following solution: ${ }^{25}$ NIXIBVS / LVCINIS / [CAE]PARIA / [---]S. The inscription of the altar is sometimes published ${ }^{26}$ - erroneously - as NIXIBVS [ET] LVCINIS, suggesting that it was dedicated for separate deities. The small size of the altar prompts for a simple dedicatory formula, the extension of the last line is probably the following: NIXIBVS / LVCINIS / [CAE]PARIA / [V(otum) L(ibens) M(eritis)] S(olvit). Thus the term Lucinae can be regared as an epitheton for the Nixus, emphasizing their role as goddesses helping childbirth and labour. ${ }^{27}$

The following line from Ovidius' Metamorphoses $(9,294)$ is also related to the cult of the Nixus: „Lucinam Nixusque pares clamore vocabam.” Based on this quote, some scholars argued that there were two Nixus, ${ }^{28}$ but we must note, that the adjective „par, paris” means „equal” or „similar”, while as a noun (meaning: „a pair of something”) it is neuter (but then the pluralis accusativus should be „paria”) or less often masculine (meaning: „a company of something"29). Thus it is not evident from the cited line of the Metamorphoses, if there were two Nixus or if they were masculine or feminine deities. ${ }^{30}$

In conclusion we can state that the interpretation of the Nixus are far from problematic - it cannot be decided with certainity if they were feminine or masculine deities (however, the altar from Aquileia hints that they should be regarded as female goddesses) or if there were two or three Nixus. Their role as deities helping labour and childbirth, as well as their connection with Iuno Lucina is quite obvious. Similar deities helping childbirth could be most probably related to the nourishing mother-goddesses (Matres or Matronae) ${ }^{31}$ that were worshipped all over the Roman Empire. Such cults were prevalent in the Celtic and Germanic areas of the Empire, but they had Mediterranean (and probably Indo-European) origins as well $^{32}$ - the worship of the Nutrices ${ }^{33}$ around Poetovio could be mentioned as a possible Pannonian parallel.

\section{c.) Matres rings (Cat. 18-19)}

Only two rings (dated to the 3rd - 4th centuries AD) from Pannonia bear dedication to the Matres, but the number of rings with similar dedications are also small from the other parts of the Roman Empire. ${ }^{34}$ The inscription of one of the Pannonian rings (Cat. 19) is written in retrograde scripture, which suggests that it was not used as a votive ring, but as a signet ring. The inscription heavily utilizes ligatures, rendering the interpretation as a sacred object even more uncertain. The Matres rings can also be connected to the worship of the mother-goddesses, similar to the Nutrices of Poetovio. ${ }^{35}$ The cult of the Nutrices in Pannonia - aside from the worship of the Nixus and the Matres - is regionally isolated (i. e. to the vicinity of Poetovio) and unique, but an altar mentioning Matres Matronae is also known from Poetovio: ${ }^{36}$ MAT(ribus) / MATRON(is) / QVI(n)TO COMIOS S(o)LV(i)T. Another altar

25 BRusin 1934, 86, Nr. 10.

26 KenNer 1989, 892-893; ŠAŠEL Kos 1999, 188.

27 Noll 1985, 159; ŠAŠEl Kos 1999, 188.

28 KenNer 1989, 892-893.

29 cf. Ovidius, Fasti, 3, 526 - here the same word is used explicitly meaning "company".

30 Noll 1985, 159-162; Kenner 1989, 892-894; ŠAšEl Kos 1999, 188-189.

31 See above.

32 cf. Stauffer 1984, 1457-1466.

33 Šašel Kos 1999, 187-192.

34 RIB 2422.9, 2422.22(?), 2422.28

35 ŠAŠEL Kos 1999, 153-192.

36 AE 1982, 793. 
from Lugdunum ${ }^{37}$ contains the dedication MA/TRONIS ET MATRIBVS / PANNONIORVM ET/ DELMATARVM. As we have mentioned above, the cult of the Matres were prevalent mainly in the Germanic (and to a lesser extent in the Celtic) areas of the Roman Empire, ${ }^{38}$ but their cult had undoubtedly some Mediterranean origins as well. ${ }^{39}$ Nevertheless, the two mentioned altars and the two Pannonian rings dedicated to the Matres attests that their cult was also present in Pannonia, at least in the vicinity of the Amber Road.

\section{d.) Rings dedicated to the traditional Roman deities (Cat. 2O-22)}

While numerous examples of inscribed rings dedicated to the gods of the traditional Roman pantheon are known from the northwestern provinces of the Roman Empire, ${ }^{40}$ only three of such rings can be mentioned from Pannonia.

In the inscription of a golden ring from Intercisa (Cat. 20), we can recognize the dative form Iovi - TAME / IOVI / TA. The words "TAME (...) TA" could perhaps be interpreted as the vulgarized form ${ }^{41}$ of „,da me (...) $d a$ ” (i. e. „Da me, Iovi, da!'), ${ }^{42}$ thus suggesting a votive use of the ring. Another silver ring from Carnuntum (Cat. 21) bears the inscription IOV(i). Rings dedicated to Iuppiter are well-known from other parts of the Roman Empire as well ${ }^{43}$ (Fig. 1b).

A bronze ring from Brigetio (Cat. 22) displays the inscription $M I{ }^{44}$ which was interpreted by L. Borhy as the vocative case of the possessive pronoun meus, mea, meum, ${ }^{45}$ but based on some analogies from Germania ${ }^{46}$ (Fig. 1d-e), we must consider other readings of the inscription as well, such as MI(nervae) or less likely MI(rcurio). ${ }^{47}$

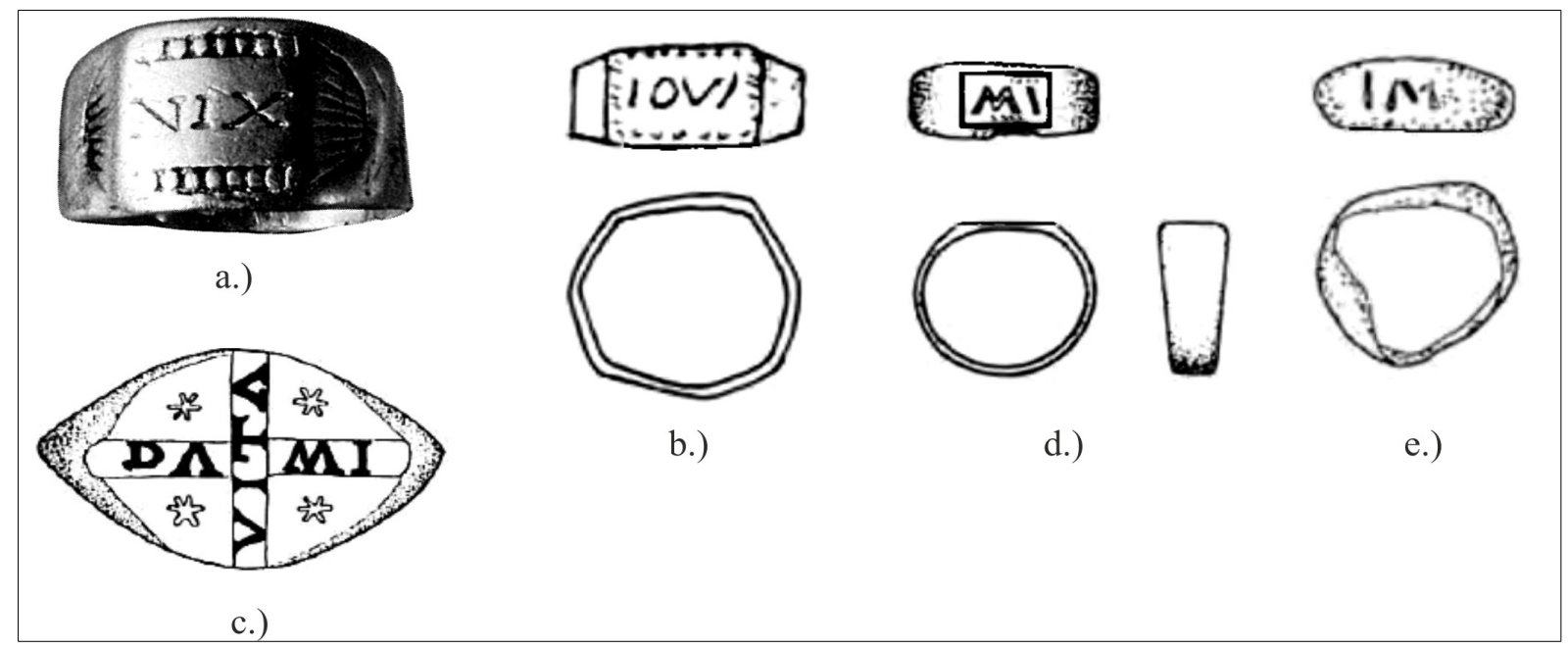

Fig. 1. a. Rembrechts (D) - NIX(ibus) (Noll 1985, Abb. 1); b. Großprüfening (D) - IOVI (PfAHL 2012, Nr. 149); c. London (UK) - DA MI / VITA (RIB 2422.75); d. Eching-Berghofen (D) - MI(nervae?) (PFAHL 2012, Kat. Nr. 156); e. Wallheim (D) - MI(nervae?) (PFAHL 2012, Kat. Nr. 150).

37 CIL XIII, 1766 = ILS 4794.

38 ŠAŠEL Kos 1999, 188.

39 STAUFFER 1984, 1457-1463.

40 Britannia: RIB 2422.20, 2422.23, 2422.26, 2422.29-30; Germania: Pfahl 2012, Nr. 21-23, 27-28, 32-37, 149-150, 154-160.

$41 \mathrm{cf}$. RIB 2422.75 (Londinium/UK) - DA MI / VITA. (2nd century AD) - Considering the Britannian analogy (Fig. 1c), we could read the inscription of the ring from Intercisa as „Ta me $\{\mathrm{IO}\}$ vita?", but that would not give any plausible explanations for the interpretation of the letters $\{I O\}$.

42 For the palatalisation of the $d$ and $t$ consonants in vulgar Latin, see FeHÉr 2007, 384-387.

43 Pfahl 2012, Nr. 19: IOVI OPTIM(o), Nr. 21: I(ovi) O(ptimo) V(oti) C(ompos), Nr. 149: IOVI.

44 cf. PfaHL 2012, Nr. 150: IM - the reading suggested by S. Pfahl is IVN(oni).

45 BORHY - SZÁMADÓ 2003, 53.

46 Pfahl 2012, Nr. 156. - MI(nervae), Nr. 33-36, Nr. 157-160: MIN(ervae), Nr. 37: MINE(ervae).

47 cf. PfaHL 2012, Nr. 27. - MII(rcurio). 


\section{e.) Rings with other sacred inscriptions (Cat. 23-28)}

A distinct group is formed by some Pannonian inscribed rings with unparalleled, uncertain or even apparently incomprehensible readings. The inscription of a silver ring from unknown Pannonian provenance (Cat. 23) was held undecipherable by E. Tóth, however he could read the word votum on the ring. ${ }^{48} \mathrm{~A}$ more complete reading can be suggested as the following: $E N O+I I V L I V(s) \operatorname{VOTV}(m)$ POSVI<t?>, implying an unambigously votive usage.

Two other silver rings (Cat. 24-25) from unknown provenance feature apparently meaningless inscriptions, which are usually regarded as undecipherable by scholars. ${ }^{49}$ Some inscribed rings from Britannia (Fig. 2) may bring us closer to the interpretation of the Pannonian rings. The rings from Britannia ${ }^{50}$ constitute a coherent group from an archaeological and epigraphical aspect: four polygonal bronze rings, whose segments bear the same seven incised letters, but in different order. The rings were most probably made in the same place, and contain the randomly mixed up letters of the very same inscription. One of the Britannian rings was found in a Romano-Celtic shrine, ${ }^{51}$ (Fig. 2a) which further corroborates the assumption, that these rings should be regarded as objects of religious importance with sacred inscriptions. R. P. Wright argued ${ }^{52}$ that the original inscription contained the name of a deity (Couxssius?), and that its letters were mixed up in different permutations for religious reasons. The apparently random sequence of letters on the Pannonian rings may also be interpreted in the likeness of the Britannian rings, i. e. as mixed up letters, originally forming the name of a deity or a votive formula. ${ }^{53}$

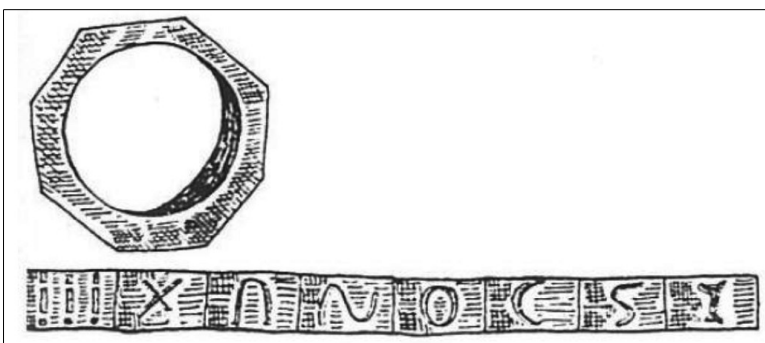

a.)

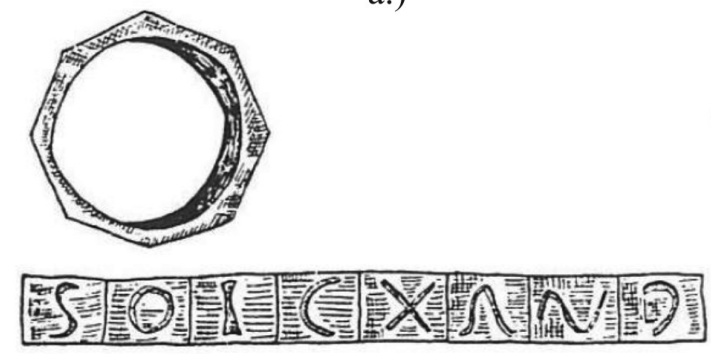

c.)

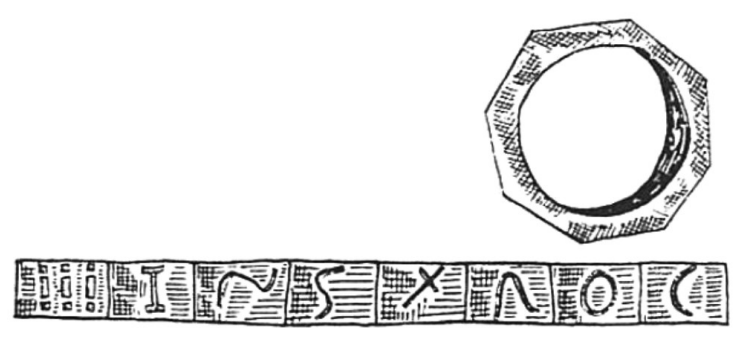

b.)

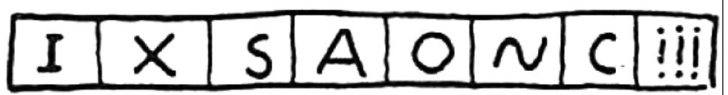

d.)

Fig. 2. a. Henley Wood (UK) - XANOCSI (RIB 2422.54); b. Owslebury (UK) - INSXAOC (RIB 2422.55); c. Owslebury (UK) - SOICXAN (RIB 2422.56); d. Caistor St. Elmund (UK) - IXSAONC (RIB 2422.53).

48 Тótн 1980, 139. Nr. 29.

49 Tótн 1980, 139. Nr. 28: ADERCNE; SzABó 2011, 108, No. 2: SNTIGMION(?).

50 RIB 2422.53 (Caistor St. Edmund/UK): IXSAONC; RIB 2422.54 (Yatton/UK): XANOCSI; RIB 2422.55 (Owslebury/UK): INSXAOC; RIB 2422.56 (Owslebury/UK): SOICXAN.

51 WRIGHT 1970, 311.

52 Wright 1970, 312.

53 Note that the letters of the silver ring bearing the inscription ADERCNE (Cat. 24.) can form the word "deae". 
Another silver ring that was found in Értény $(\mathrm{H})$ (Cat. 26) features a hardly readable inscription, mainly due to its poor condition. E. Tóth suggested ${ }^{54}$ the reading $D A[---] E G[---] I A[-]$ EGET XC, albeit at least one Greek $\left(, \Gamma^{\prime \prime}\right)$ letter is also recognizable on the ring, thus we suggest

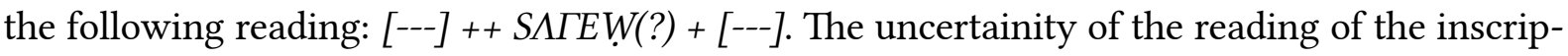
tion renders the interpretation of the ring as a religious object highly hypothetical. Two other rings, one from unknown Pannonian findspot (Cat. 27) and one from Cibalae (Cat. 28) do not contain de facto inscriptions, but rather a series of signs, whose closest parallels are charaktêrés implemented during magical practices. According to the various sources of ancient magic, such rings could have been used for performing divination or preparing defixiones. ${ }^{55}$

\section{Conclusions}

Rings with sacred inscriptions are represented in Pannonia by a relatively few objects, however such objects are of great importance in the study of Roman religion - Pannonian rings with sacred inscriptions can be divided into five groups. The so-called a.) Silvanus rings (Cat. 1-12) are being considered by the scholarly research as rings with sepulchral functions, albeit their exact usage can not always be specified with certainity based on their inscriptions, since only two rings are known from a closed context. b.) The Nixus rings (Cat. 13-17) and c.) the Matres rings (Cat. 18-19) were dedicated to goddesses related to childbirth and nourishment. Such goddesses are rarely and isolately attested on other kinds of inscriptions in the territory of Pannonia. Among the d.) rings dedicated to the traditional Roman deities (Cat. 20-22), we can mention two rings dedicated to Iuppiter and perhaps one to Minerva or Mercurius. e.) Other rings with sacred inscriptions (Cat. 23-28) include rings that may be interpreted as magical objects (Cat. 27-28.) and rings displaying apparently random letter sequences (Cat. 24-25), which could be regarded as sacred inscriptions, based on some Britannian parallels.

\section{Catalogue}

a.) Silvanus rings

1. Silver ring (Fig. 3)

Findspot: Unknown (NE-Transdanubia)

Dimensions: $\mathrm{D}=2,8 \mathrm{~cm}$

Inventory: Hungarian National Museum

Inv. No.: -

Literature: SzABó 2010, 223-228.

Datation: 4th century AD

Inscription: SILVANI ${ }^{\circ}$ VOTI RIESI.

\section{Silver ring (Fig. 3)}

Findspot: Unknown (Pannonia)

Dimensions: $\mathrm{D}=2,6 \mathrm{~cm}$

Inventory: Hungarian National Museum

Inv. No.: RR 2010.4.1.

Literature: SzaBó 2011, 107, No. 1, 1. kép a-d.

Datation: 4th century AD

Inscription: ȘILVANO VIATTOQRI

\section{Silver ring (Fig. 3)}

Findspot: Gerulata (Rusovce/SK)

Dimensions: $\mathrm{D}=3 \mathrm{~cm}$

Inventory: $\mathrm{n} / \mathrm{a}$.

Literature: Tóтн 1978, 91, Nr. 1, Abb. 1.

Datation: First half of the 4th century AD

Inscription: V(oco) SILVANVM VIATOREM

\section{Golden ring (Fig. 3)}

Findspot: Scarbantia (Sopron/H)

Dimensions: $\mathrm{D}=2,1 \mathrm{~cm}$

Inventory: Hungarian National Museum

Inv. No.: RR 39/1909.

Literature: Tóth 1978, 92, Nr. 2, Abb. 2-3;

То́тн 1979, 166, Nr. 13, Abb. 7, 13.

Datation: First half of the 4th century AD

Inscription: S(ilvano) S(acrum) VRSINI(us) V(otum) L(ibens) M(erito) S(olvit) 


\section{Golden ring (Fig. 3)}

Findspot: Savaria (Szombathely/H)

Dimensions: $\mathrm{D}=2,3 \mathrm{~cm}$

Inventory: Hungarian National Museum

Inv. No.: RR 18/1909.

Literature: То́тн 1978, 92, Nr. 3, Abb. 4; Tо́тн 1979, 166, Nr. 12, Abb. 6, 12.

Datation: First half of the 4th century AD (?)

Inscriptions: VOTVM SILVANO

\section{Silver ring (Fig. 3)}

Findspot: Keszthely-Fenékpuszta $(\mathrm{H})$

Dimensions: $\mathrm{D}=2,1 \mathrm{~cm}$

Inventory: $\mathrm{n} / \mathrm{a}$.

Literature: Tóтн 1978, 92, Nr. 4, Abb. 5-6.

Datation: 4th century AD

Inscription: S(anc)TE SILVANE

\section{Silver ring}

Findspot: Unknown (Veszprém c./H)

Dimensions: $\mathrm{n} / \mathrm{a}$

Inventory: n/a.

Literature: Tótн 1978, 92, Nr. 5.

Datation: 4th century AD

Inscription: SILVANO [v]OTVM

\section{Silver ring (Fig. 3)}

Findspot: Bogád $(\mathrm{H})$

Dimensions: $\mathrm{D}=1,9 \mathrm{~cm}$

Inventory: $\mathrm{n} / \mathrm{a}$.

Literature: BURGER 1962, 118; Tóth 1978, 92,

Nr. 6, Abb. 7.

Datation: 4th century AD

Inscription: $S I^{\wedge} L V^{\wedge} A N O$ VIATORI

\section{Silver ring (Fig. 3)}

Findspot: Iovia (Alsóhetény/H)

Dimensions: $\mathrm{D}=2,5 \mathrm{~cm}$

Inventory: Hungarian National Museum

Inv. No.: RR 84.11.1.

Literature: Tótн 1989, 114, Nr. 1, Abb. 1, 6.

Datation: 4th century AD

Inscription: SILVANO VIATO(ri)

10. Silver ring (Fig. 3)

Findspot: Unknown (Pannonia)

Dimensions: $\mathrm{D}=2,2 \mathrm{~cm}$

Inventory: Hungarian National Museum

Inv. No.: RR 87.4.1.

Literature: Tóth 1989, 114, Nr. 2, Abb. 1, 1.

Datation: 3rd century AD

Inscription: [Si]LVA[n(o)] SILV(estris)
11. Silver ring (Fig. 3)

Findspot: Brigetio (Komárom/H)

Dimensions: $\mathrm{D}=2,6 \mathrm{~cm}$

Inventory: Klapka György Múzeum

Inv. No.: 2003.SL.1.1.

Literature: BORHY - SzÁMADÓ 2003, 53, Kat. 73.

Datation: 4th century AD

Inscription: $\operatorname{VOTV}(m) \quad$ SILVANO $V(?) \quad M(?)$

VI[atori?]

12. Silver ring fragment (Fig. 3)

Findspot: Zurndorf (A)

Dimensions: $1,6 \times 0,7 \mathrm{~cm}$

Inventory: $\mathrm{n} / \mathrm{a}$

Literature: FbÖ 27 (1988), 302, Abb. 461.

Datation: 4th century $\mathrm{AD}$

Inscription: [Silva]NI[---?]

\section{b.) Nixus rings}

\section{Silver ring fragment (Fig. 4)}

Findspot: Carnuntum (Bad Deutsch-Altenburg/A)

Dimensions: $1,5 \times 1 \mathrm{~cm}$

Inventory: Private collection (Kunsthistorisches Museum, Inv.-Nr.: VII.1028.)

Literature: Noll 1985, 159, Abb. 2.

Dating: 1 st -4 th century $A D$

Inscription: NIX(ibus)

14. Golden ring (Fig. 4)

Findspot: Carnuntum (Bad Deutsch-Altenburg/A)

Dimensions: $\mathrm{D}=1,7 \mathrm{~cm}$

Inventory: Museum Carnuntinum

Inv. No.: 11.905 .

Literature: Noll 1985, 160. Abb. 3.

Datation: $\mathrm{n} / \mathrm{a}$

Inscription: $N \cdot I \bullet X \bullet($ ibus $) / V \cdot O \bullet T(u m)$

15. Silver ring fragment (Fig. 4)

Findspot: Carnuntum (Bad Deutsch-Altenburg/A)

Dimensions: $1,8 \times 2 \mathrm{~cm}$

Inventory: Private collection

Literature: NolL 1985, 161, Abb. 4.

Datation: 2nd - 3rd century AD

Inscription: NIX(ibus)

16. Silver ring (Fig. 4)

Findspot: Carnuntum (Petronell/A)

Dimensions: $\mathrm{D}=1,9 \mathrm{~cm}$

Inventory: $\mathrm{n} / \mathrm{a}$

Literature: FbÖ 30 (1991), 302, Abb. 945.

Datation: 2nd - 3rd century AD

Inscription: NIX(ibus) 
17. Silver ring (Fig. 4)

Findspot: Mannersdorf (A)

Dimensions: $2,5 \times 2 \mathrm{~cm}$

Inventory: Private collection

Literature: Noll 1985, 162, Abb 5.

Datation: 2nd - 3rd century AD

Inscription: NIX(ibus)

\section{c.) Matres rings}

\section{Silver ring (Fig. 4)}

Findspot: Andau (A)

Dimensions: $\mathrm{D}=2,1 \mathrm{~cm}$

Inventory: $\mathrm{n} / \mathrm{a}$

Literature: FbÖ 37 (1998), 746, Abb. 431.

Datation: 4 th century $\mathrm{AD}$

Inscription: MATR(ibus)

19. Golden ring (Fig. 4)

Findspot: Unknown (Pannonia)

Dimensions: $\mathrm{D}=\mathrm{n} / \mathrm{a}$

Inventory: Hungarian National Museum

Inv. No. RR 108/1886.

Literature: Tótн 1979, 158-160, Nr. 4, Abb. 2, 4.

Datation: 3rd - 4th century AD

Inscription: $M^{\wedge} A^{\wedge} T^{\wedge} R(i) S$ (?) or

$M^{\wedge} A^{\wedge} T^{\wedge} R(i b u) S(?)$

\section{d.) Rings dedicated to the traditional Roman deities}

20. Golden ring (Fig. 4)

Findspot: Intercisa (Dunaújváros/H)

Dimensions: $\mathrm{D}=1,25 \mathrm{~cm}$

Inventory: Hungarian National Museum

Inv. No.: RR 62.417.21.

Literature: Tótr 1979, 158, Nr. 1, Abb. 1, 1.

Datation: 2nd century AD

Inscription: TAME|IOVI]/TA

\section{Silver ring (Fig. 4)}

Findspot: Carnuntum (Bad Deutsch-Altenburg/A)

Dimensions: $\mathrm{D}=2,6 \mathrm{~cm}$

Inventory: $\mathrm{n} / \mathrm{a}$

Literature: FbÖ 27 (1988), 308, Abb. 596.

Datation: 2nd - 3rd century AD

Inscription: $\operatorname{IOV}(i)$

\section{Bronze ring (Fig. 4)}

Findspot: Brigetio (Komárom/H)

Dimensions: $\mathrm{D}=1,8 \mathrm{~cm}$

Literature: BORHY - SzÁMADÓ 2003, 53, Kat. 72.

Inventory: Klapka György Múzeum

Inv. No.: 992.SZ.227.1115.

Datation: 2nd - 3rd century AD

Inscription: MI(nervae?)

\section{e.) Rings with other sacred inscriptions}

23. Silver ring (Fig. 4)

Findspot: Unknown (Pannonia)

Dimensions: $\mathrm{D}=2,25 \mathrm{~cm}$

Inventory: Hungarian National Museum

Inv. No.: RR 10/1882.1.

Literature: Tóтн 1980, 139, Nr. 29, Abb. 7.

Datation: 3rd - 4th century AD

Inscription: $E N O+I I V L I V(s)$ VOTV $(m)$ POSVI<t?>

24. Silver ring (Fig. 4)

Findspot: Ismeretlen lh. (Pannonia)

Dimensions: $\mathrm{D}=2,1 \mathrm{~cm}$

Inventory: Hungarian National Museum

Inv. No.: RR 63.1.14.

Literature: Tótн 1980, 139, Nr. 28, Abb. 6; HaInZMANN - VIsY 1991, 112, Kat.-Nr. 150.

Datation: End of 3rd century - 4th century AD Inscription: $A D E R C N E$

25. Silver ring (Fig. 5)

Findspot: Ismeretlen (Pannonia)

Dimensions: $\mathrm{D}=2,5 \mathrm{~cm}$

Inventory: Hungarian National Museum

Inv. No.: RR 2010.4.2.

Literature: SzABó 2011, 108, No. 2, 2. kép a-c.

Datation: 3rd - 4th centuries AD

Inscription: SNTIGMION(?)

\section{Silver ring (Fig. 4)}

Findspot: Értény-Barnahát (H)

Dimensions: $\mathrm{D}=\mathrm{n} / \mathrm{a}$

Inventory: Hungarian National Museum

Inv. No.: RR 225/1873.5.

Literature: TóTH 1980, 140, Nr. 30.

Datation: 4th century $\mathrm{AD}(?)$

Inscription: DA[---] EG[---] IA[-] EGET XC

(Тóтн 1980) or ++ SAГEW(?) + [---]

\section{Silver ring (Fig. 5)}

Findspot: Unknown (Pannonia)

Dimensions: $\mathrm{D}=2,6 \mathrm{~cm}$

Inventory: Hungarian National Museum

Inv. No.: RR 2010.4.3.

Literature: SzABó 2011, 109, No. 3, 3. kép a-c.

Datation: 3rd - 4th centuries AD

Inscription: III X K (charaktér) $\Lambda$ I Y N $\Lambda \bullet A I I / I K \bullet$

28. Silver ring (Fig. 5)

Findspot: Cibalae (Vinkovci/HR)

Dimensions: $\mathrm{D}=2,4 \mathrm{~cm}$

Inventory: Arheološki muzej u Zagrebu (lost)

Literature: MigotTi 1997, 16-17, G.4.

Datation: 3rd - 4th centuries AD

Inscription: 12 charaktêrés 


\begin{abstract}
Abbreviations
$\mathrm{AE}=$ L'Année épigraphique

$\mathrm{CIL}=$ Corpus Inscriptionum Latinarum

ILS = Inscriptiones Latinae Selectae

FbÖ = Fundberichte aus Österreich

RIB $=$ The Roman Inscriptions of Britain

TitAq $=$ Tituli Aquincenses
\end{abstract}

\title{
References
}

Bonner, C. 1950: Studies in Magical Amulets Chiefly Graeco-Egyptian. Ann Arbor.

Borhy, L. - SzÁmadó, E.: Gemmák, gemmás gyürük és ékszerek Brigetióban. Acta Archaeologica Brigetionensia. Ser. I. Vol. 4. Komárom.

Brusin, G. 1934: Gli scavi di Aquileia. Udine.

Burger, A. 1962: A bogádi későrómai temető. Das spätrömische Gräberfeld von Bogád. Janus Pannonius Múzeum Évkönyvei 7, 111-136.

Dorcey, P. F. 1992: The Cult of Silvanus. A Study in Roman Folk Religion. Leiden - New York - Köln.

Entwistle, C. - Adams, N. (eds.) 2011: Gems of Heaven. Recent Research on Engraved Gemstones in Late Antiquity c. AD 200-600. London.

Facsády, A. 2009: Aquincumi ékszerek. Jewellery in Aquincum. Az Aquincumi Múzeum Gyüjteménye 1. Budapest.

FeHÉr, B. 2007: Pannonia latin nyelvtörténete. Budapest.

Fourlas, A. A. 1971: Der Ring in der Antike und im Christentum. Der Ring als Herrschaftssymbol und Würderzeichen. Forschungen zur Volkskunde Heft 45. Münster.

FứöH, D. 2011: Előzetes jelentés az Ács Öbölkúti-dűlő - a Csoma \& Scott Szélerőműpark - területén végzett régészeti feltárásról. Agria 47, 109-120.

Henkel, F. 1913: Die römischen Fingerringe der Rheinlande und der benachbarten Gebiete. Berlin.

Kenner, H. 1989: Die Götterwelt der Austria Romana. In: HaAse, W. - Temporini, H. (eds.): Aufstieg und Niedergang der römischen Welt II,18.2. Berlin - New York, 875-974.

KRAsKovskÁ, L. 1974: Gerulata Rusovce: Rímske pohrebisko I. Bratislava.

Kropp, A. 2008: Defixiones. Ein aktuelles Corpus lateinischer Fluchtafeln. Speyer.

MicheL, S. 2004: Die magischen Gemmen. Berlin.

Migotti, B. 1997: Evidence for Christianity in Roman Southern Pannonia (Northern Croatia). British Archaeological Reports. International Series 684. Oxford.

NAGy, Á. M. 2013: A varázsgemmák. In: NAGy, Á. M. (ed.): Az Olympos mellett. Mágikus hagyományok az ókori Mediterraneumban. Budapest, 793-810.

NemÉNyi, R. 2014: Ókeresztény szimbólummal ellátott késő antik hagymafejes fibulák a Római Birodalomban. Unpublished MA-thesis. Pécs.

Noll, R. 1974: Eine goldene 'Kaiserfibel' aus Niederemmel vom Jahre 316. Bonner Fahrbücher 174, 221-244. 
Noll, R. 1985: Nixibus. Vier neue Belege für die Geburtsgöttinnen aus dem Raum von Carnuntum. Germania 63, 159-163.

PfaHL, S. 2012: Instrumenta Latina et Graeca Inscripta des Limesgebietes von 200 v. Chr. bis 600 n. Chr. Weinstadt.

ŠAšEl Kos, M. 1999: Pre-Roman Divinities in the Eastern Alps and Adriatic. Situla 38. Ljubljana.

SPIER, J. 2007: Late Antique and Early Christian Gems. Wiesbaden.

Stauffer, E. 1984: Antike Madonnen-religion. In: HAase, W. - Temporini, H. (eds.): Aufstieg und Niedergang der römischen Welt II,17.3. Berlin-New York, 1425-1499.

Szabó, Á. 2008: 'Suscepta fide ex orco' (ad CIL III 2624). In: Szabó, Á. - Vargyas, P. (eds.): Cultus Deorum Vol. II. De rebus aetatis Graecorum et Romanorum. In memoriam István Tóth. Budapest, 161166.

Szaвó, Á. 2010: Új Silvanus gyürü Pannoniából. In: KovÁcs, P. - Szaвó, Á. (eds.): Studia Epigraphica Pannonica Vol. II. Budapest, 223-228.

Szabó, Á. 2011: Újabb feliratos gyűrűk Pannoniából. In: Kovács, P. - FehÉr, B. - SzABó, Á. (eds.): Studia Epigraphica Pannonica Vol. III. Budapest, 107-111.

SzABó, A. (manuscript): Magical(?) rings from Pannonia. (manuscript; in press)

Tóтн, E. 1978: Silvanus Viator. Alba Regia 18, 91-104.

TóтH, E. 1979: Römische Gold- und Silbergegenstände mit Inschriften im Ungarischen Nationalmuseum: Goldringe. Folia Archaeologica 30, 157-184.

Tóтн, E. 1980: Römische Metallgegenstände mit Inschriften aus dem Ungarischen Nationalmuseum: Instrumenta domestica. Folia Archaeologica 31, 131-156.

TóTH, E. 1986: Római gyưrük és fibulák. Évezredek, évszázadok kincsei 3. Budapest.

Tóтн, E. 1989: Neuere Silvanusringe aus Pannonien. Folia Archaeologica 40, 113-127.

TóтH, E. 1997: A későantik ifjúarckép-medaillonok értelmezéséhez. Zur Interpretation der spätantiken Medaillons mit Jünglingsportäts. Komárom-Esztergom Megyei Múzeumok Közleményei 5, 363-387.

Tóтн, E. 2008: A székesfehérvári ókeresztény korláttöredék. Archaeologiai Értesítő 133, 49-66.

Tóth, I. 2004: Pannoniai vallástörténet. Unpublished doctoral thesis at the Hungarian Academy of Sciences. Pécs.

Wissowa, G. 1912: Religion und Kultus der Römer. München (2nd edition).

Wright, R. P. 1970: Roman Britain in 1969. II. Inscriptions. Britannia 1, 305-315. 


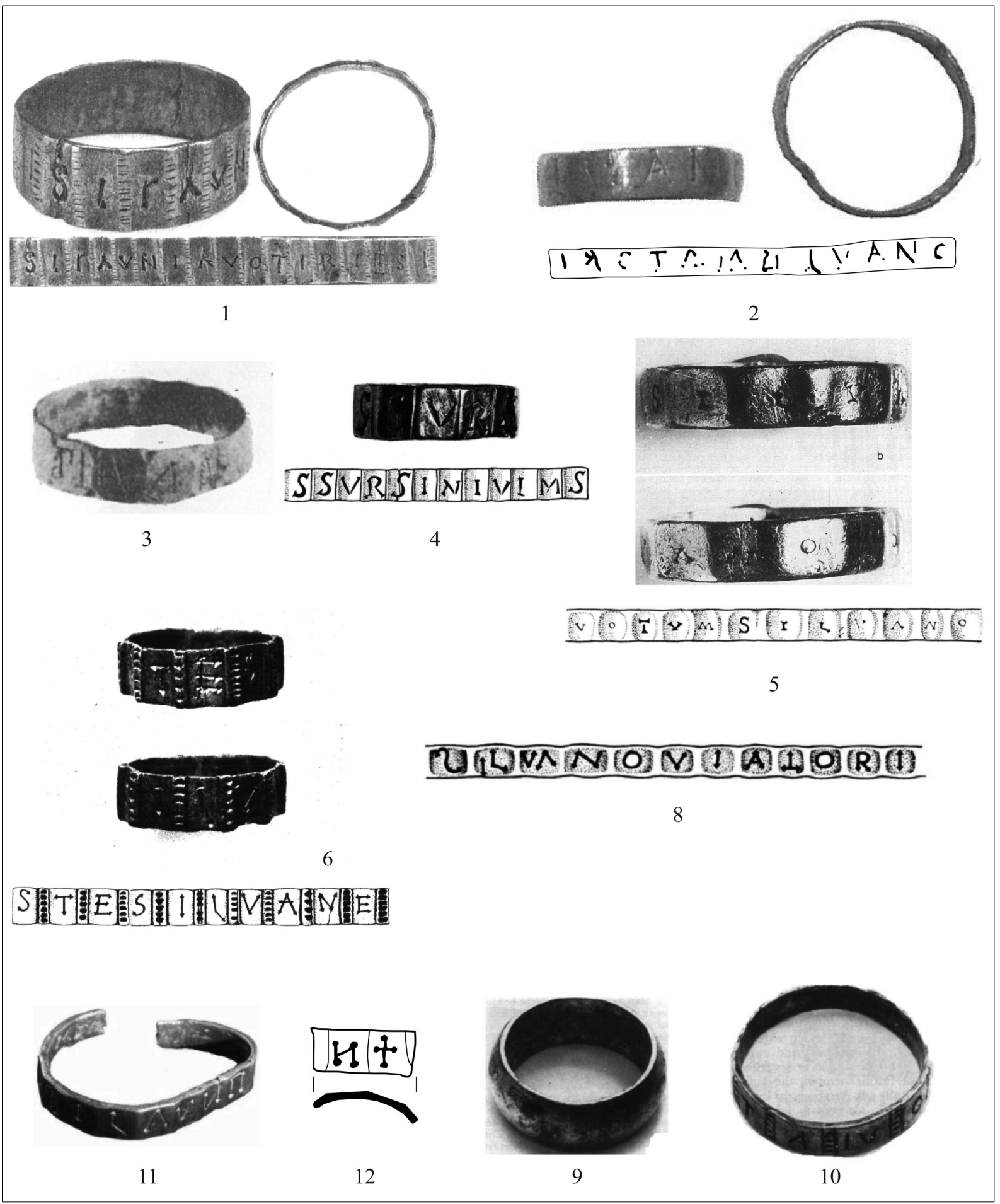

Fig. 3. Cat. 1-6, 8-12. 


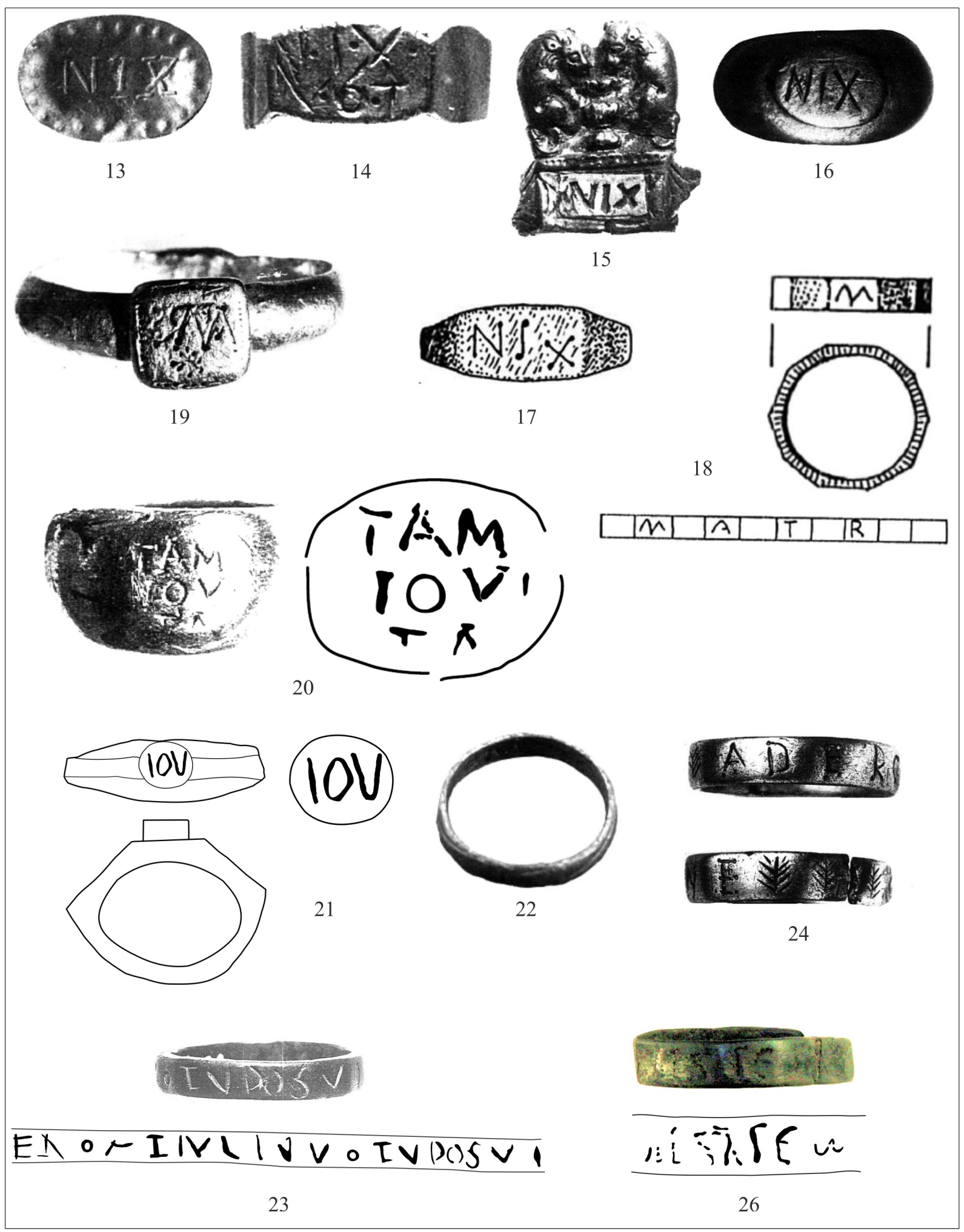

Fig. 4. Cat. 13-24, 26. 


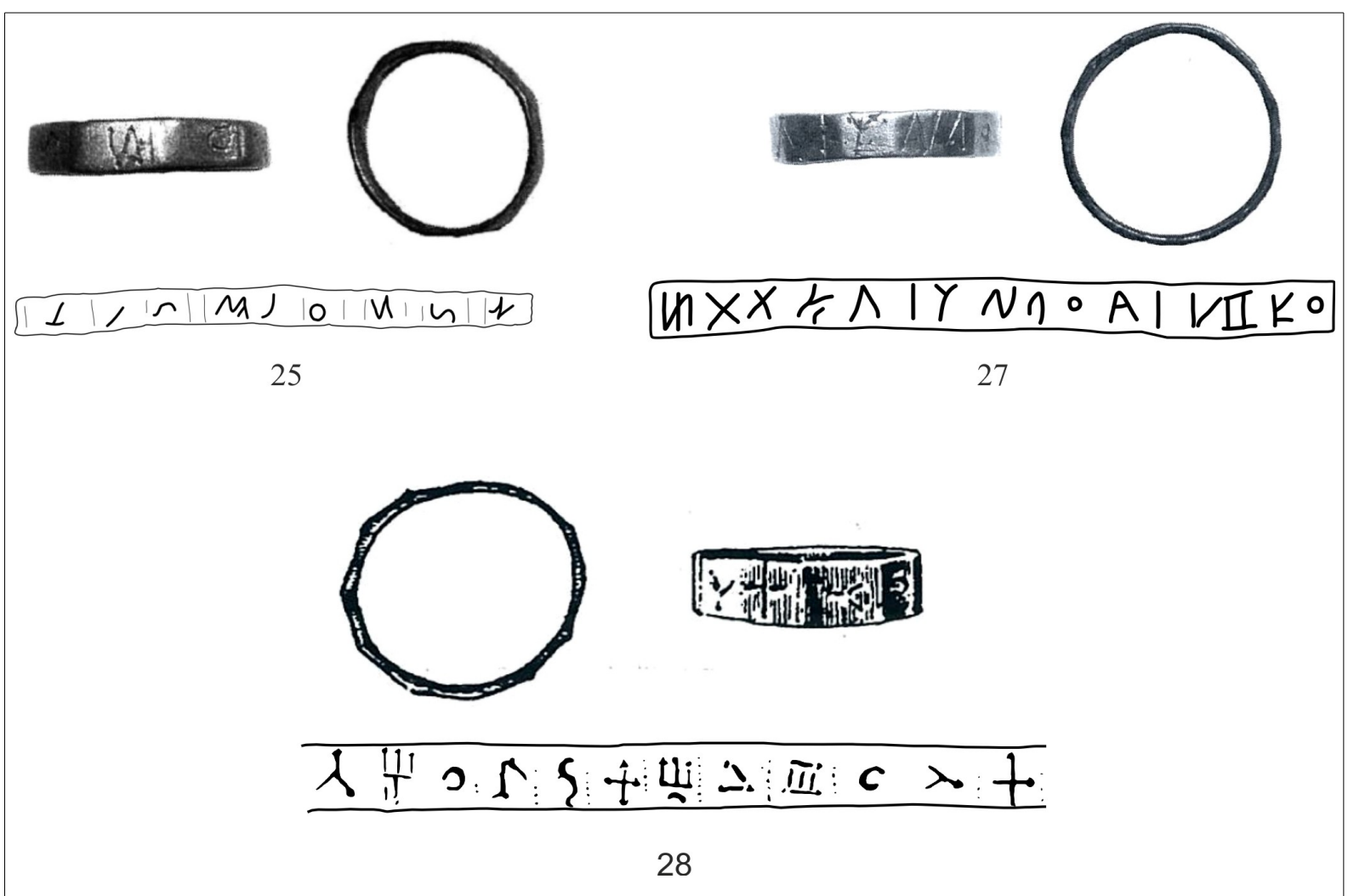

Fig. 5. Cat. 25, 27-28. 